\title{
METHEMALBUMIN. I. APPEARANCE DURING ADMINISTRATION OF PAMAQUINE AND QUININE ${ }^{1,2}$
}

\author{
By MORRIS ROSENFELD, ${ }^{3}$ CHARLES G. ZUBROD, ${ }^{3}$ WILLIAM D. BLAKE, ${ }^{3}$ \\ AND JAMES A. SHANNON \\ (From the Department of Medicine, New York University College of Medicine, and the \\ Research Service, Third [New York University] Medical Division, Goldwater \\ Memorial Hospital, New York City, and the Department of Pharmacology \\ and Experimental Therapeutics, The Johns Hopkins University, \\ Baltimore, Maryland)
}

(Received for publication March 12, 1947)

Hematin was first identified by Schumm (1) as an abnormal constituent of blood plasma occurring in certain hemolytic states. The fact that this pigment does not circulate as free hematin but is combined with serum protein was suspected by Heilmeyer (2) on the basis of a displacement of one of the hematin absorption bands in the presence of serum. The serum albumin-hematin complex was first adequately described and differentiated from methemoglobin by Fairley and Bromfield (3) who studied the pigment in cases of blackwater fever. Fairley (4) named the compound "methaemalbumin" and presented a detailed characterization of its spectrophotometric properties, synthesis and chemical behavior. Spectrograms of the pigment as it occurs in serum of patients with blackwater fever were published by Foy and Kondi (5). Fox (6) based an analytical procedure for the estimation of methemalbumin on the intensity of the absorption band at $623 \mathrm{~m} \mu$ and its response to certain reagents, sodium cyanide and hydrogen peroxide. The nature of the reaction between hematin and serum albumin was recently examined by J. Keilin (7). The metabolic disposition of methemalbumin is treated in the

\footnotetext{
1 This work was carried out under a contract, recommended by the Committee on Medical Research, between the Office of Scientific Research and Development and New York University.

2 The authors express their thanks to the Malaria Study Section of the National Institute of Health for editorial assistance and for arrangements in regard to the publication of this paper. They are also grateful to the Abbott Laboratories, E. I. du Pont de Nemours and Company, Inc., E. R. Squibb and Sons, Eli Lilly and Company, Sharp and Dohme, and Wyeth, Inc., for contributing toward the publication costs.

3 Captain, MC, AUS.
}

paper of Pass, Schwartz and Watson (8) on the fate of intravenously injected hematin.

Methemalbumin has not been demonstrated in normal serum as an intermediary in the metabolism of hemoglobin. It has been observed only as an abnormal serum constituent. In addition to his findings in blackwater fever Fairley (9) demonstrated methemalbuminemia in cases of severe malaria, nocturnal hemoglobinuria, gas bacillus sepsis and pernicious anemia. More recently it has been observed in hemolytic reactions to sulfonamides by Fox and Ottenberg (10) and by Ross and Paegel (11) and in pamaquine hemoglobinuria by Dimson and McMartin (12).

Early in the course of studies conducted at the Goldwater Memorial Hospital on the use of pamaquine in malarial therapy there was encountered an acute hemolytic reaction clinically indistinguishable from blackwater fever. Methemalbumin, in addition to free hemoglobin, was detected in the serum of this patient. This observation directed attention to the abnormal blood pigment.

The antimalarial program included an evaluation of the curative action of pamaquine-quinine therapy. The subjects receiving therapy under this program afforded an opportunity for more detailed study which led to the observation that individuals receiving the combined drug therapy consistently developed methemalbuminemia. Controls receiving either drug alone failed to do so. Whereas in previous studies the pigment appeared in sporadic cases in which the precipitating factors were ill-defined, the present work brings to light the uniform occurrence of the pigment under readily reproducible conditions of drug administration. 
TABLE I

Concentration of serum methemalbumin, methemoglobin, hemoglobin, and serum bilirubin during administration of antimalarial drugs

\begin{tabular}{|c|c|c|c|c|c|c|c|}
\hline & \multirow{3}{*}{ Patient } & \multirow{3}{*}{$\begin{array}{c}\text { Serum } \\
\text { methemal- } \\
\text { bumin } \\
\text { as hemin } \\
(m g . / L)\end{array}$} & \multirow{3}{*}{$\begin{array}{l}\text { Methemo- } \\
\text { globint as } \\
\text { per cent } \\
\text { of total } \\
\text { hemoglobin }\end{array}$} & \multicolumn{2}{|c|}{$\underset{(\mathrm{gm} . / 100 \mathrm{ml} .)}{\text { Hemoglobin }}$} & \multicolumn{2}{|c|}{$\begin{array}{l}\text { Total serum bilirubin } \\
(m g . / 100 \mathrm{ml} .)\end{array}$} \\
\hline & & & & \multicolumn{2}{|c|}{ Day of treatment } & \multicolumn{2}{|c|}{ Day of treatment } \\
\hline & & & & 4 & 14 & 4 & 14 \\
\hline $\begin{array}{c}\text { Group I } \\
\text { Quinine- } \\
\text { Pamaquine }\end{array}$ & $\begin{array}{l}\text { Fl } \\
\text { Bu } \\
\text { Sw } \\
\text { Cl } \\
\text { Mo }\end{array}$ & $\begin{array}{r}20 \\
22 \\
24 \\
9 \\
4\end{array}$ & $\begin{array}{r}19 \\
21 \\
20 \\
11 \\
6\end{array}$ & $\begin{array}{l}14.5 \\
13.0 \\
13.5 \\
14.5 \\
11.0\end{array}$ & $\begin{array}{l}10.0 \\
11.5 \\
12.5 \\
14.0 \\
12.0\end{array}$ & $\begin{array}{l}1.0 \\
1.4 \\
0.9 \\
1.0 \\
1.2\end{array}$ & $\begin{array}{l}2.1 \\
1.3 \\
0.8 \\
1.0 \\
1.0\end{array}$ \\
\hline $\begin{array}{l}\text { Group II } \\
\text { Pamaquine }\end{array}$ & $\begin{array}{l}\text { We } \\
\text { No } \\
\text { Br } \\
\text { Ed } \\
\text { Go }\end{array}$ & $\begin{array}{l}0 \\
0 \\
0 \\
0 \\
0\end{array}$ & $\begin{array}{r}9 \\
1 \\
13 \\
8 \\
11\end{array}$ & $\begin{array}{l}11.0 \\
12.0 \\
10.0 \\
12.0 \\
12.5\end{array}$ & $\begin{array}{l}11.5 \\
10.5 \\
12.5 \\
14.5 \\
11.0\end{array}$ & $\begin{array}{l}0.6 \\
0.6 \\
0.7 \\
1.0 \\
-\end{array}$ & $\begin{array}{l}0.6 \\
0.6 \\
1.0 \\
1.7 \\
-\end{array}$ \\
\hline $\begin{array}{l}\text { Group III } \\
\text { Quinine }\end{array}$ & $\begin{array}{l}\mathrm{Ba} \\
\mathrm{Ma} \\
\mathrm{St} \\
\mathrm{Ho} \\
\mathrm{Bu}\end{array}$ & $\begin{array}{l}0 \\
0 \\
0 \\
0 \\
0\end{array}$ & $\begin{array}{l}1 \\
1 \\
\frac{0.3}{\overline{0.2}}\end{array}$ & $\begin{array}{l}13.5 \\
12.5 \\
10.5 \\
11.5 \\
13.5\end{array}$ & $\begin{array}{l}14.5 \\
12.0 \\
14.5 \\
13.0 \\
12.5\end{array}$ & $\begin{array}{l}1.6 \\
1.6 \\
1.2 \\
1.0 \\
0.6\end{array}$ & $\begin{array}{l}1.3 \\
0.7 \\
0.5 \\
0.5 \\
0.6\end{array}$ \\
\hline $\begin{array}{l}\text { Group IV } \\
\text { Quinacrine- } \\
\text { Pamaquine }\end{array}$ & $\begin{array}{l}\mathrm{Do} \\
\mathrm{Br} \\
\text { We }\end{array}$ & $\begin{array}{l}0 \\
0 \\
0\end{array}$ & $\begin{array}{r}14 \\
19 \\
6\end{array}$ & $\begin{array}{l}10.5 \\
12.5 \\
15.0\end{array}$ & $\begin{array}{l}12.5 \\
12.0 \\
12.5\end{array}$ & $\frac{0.7}{0.3}$ & $\frac{0.5}{0.4}$ \\
\hline
\end{tabular}

* Serum methemalbumin measurements were made on the 14th day of combined therapy.

$\dagger$ Methemoglobin concentrations represent maximal values obtained during treatment, usually attained in seven to ten days.

\section{MATERIALS AND METHODS}

The experiments were conducted on four groups of white male volunteers infected by mosquito inoculation with $P$. vivax malaria, Chesson strain. Group I, Table $\mathrm{I}$, received combined therapy of $90 \mathrm{mg}$. pamaquine and $1.8 \mathrm{gm}$. quinine daily, dosage in each case being expressed as the free base. Group II received $90 \mathrm{mg}$. pamaquine per day and Group III $1.8 \mathrm{gm}$. quinine per day. Group IV received combined therapy of $30 \mathrm{mg}$. pamaquine and $0.25 \mathrm{gm}$. quinacrine (as base) daily. Drug therapy by oral administration was started on the fifth day of fever and was continued for a two-week period. In the combined treatment quinine or quinacrine was started on the fifth day of fever, pamaquine was added 48 hours later and the two drugs were continued for the two weeks.

Blood specimens were withdrawn prior to therapy for control studies and samples were taken at various times during and after treatment. Fasting serum was employed. To avoid mechanical hemolysis blood was drawn through a No. 18 needle into an oiled syringe containing no anticoagulant. The blood was immediately centrifuged at 2000 r.p.m. for one-half hour. By this procedure a clear layer of serum is obtained separated from the red cells by a deposit of fibrin. Absorption curves in the range of $300 \mathrm{~m} \mu$ to $650 \mathrm{~m} \mu$ were measured in the Beckman spectrophotometer, using a cuvette of $10 \mathrm{~mm}$. light-path. The serum was either undiluted or in the presence of high concentrations of pigment it was diluted three- or five-fold. An aliquot was taken for bilirubin estimation.

The analytical procedure for methemalbumin makes use of the $405 \mathrm{~m} \mu$ absorption band of the pigment.

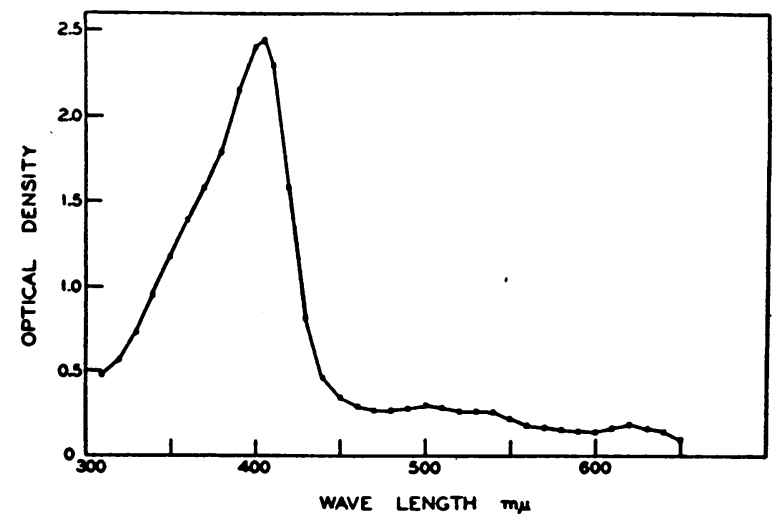

Fig. 1. Spectrophotometric Curve of MethemalbUMin Formed in VITRO by the Addition of Hematin to Purified Serum Albumin

Protein concentration $5 \mathrm{gm}$. per liter, hemin concentration 20 mg. per liter, $\mathrm{pH} 7.5$. 


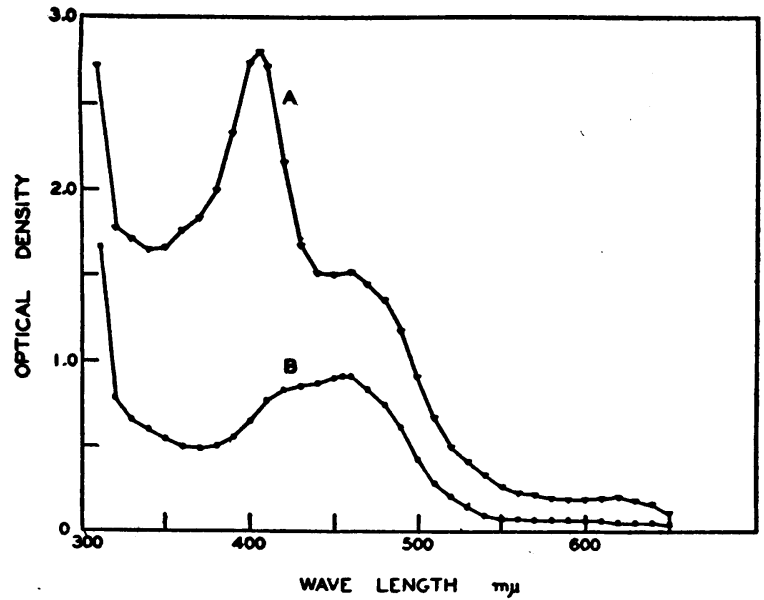

Fig. 2. Spectrophotometric Curves on Serum of a Patient Receiving Combined Therapy with PamaQUINE AND QUININE

Curve A: sample taken after two weeks of daily administration of pamaquine, $90 \mathrm{mg}$., and quinine, $1.8 \mathrm{gm}$. Curve B: control sample taken before institution of treatment.

Methemalbumin, Figure 1, exhibits absorption maxima at $405,500,540$ and $623 \mathrm{~m} \mu$. The band at $405 \mathrm{~m} \mu$ is the most intense of the series and in this respect is the most suitable for the estimation of small concentrations. The absorption curve of a serum specimen containing methemalbumin is presented in Figure 2, curve A. For comparison there is also included eurve $B$ taken on a normal, control sample drawn from the same individual before institution of drug therapy. Although calculation of methemalbumin concentration is based on one point of the curve at $405 \mathrm{~m} \mu$, the complete curve provides important information concerning the exact location of the absorption peaks and also concerning the presence or absence of interfering pigments.

The optical density at $405 \mathrm{~m} \mu$ attributable to methemalbumin is computed by subtracting the optical density of normal serum from the measured optical density of the test serum. The serum blank for this computation is taken from Figure 3 which relates the optical density of serum at $405 \mathrm{~m} \mu$ to bilirubin content. Independent chemical measurement of bilirubin in each serum under test provides the data necessary for the use of this chart. Additional information regarding the serum blank was obtained from two other sources, namely, measurement of serum taken before the institution of drug therapy, and direct estimation of the serum blank from the shape of the spectrophotometric curve of the test serum.

The optical density data are converted to methemalbumin concentration which is expressed in terms of hemin (ferri protoporphyrin chloride) equivalent. One unit of optical density in a $10 \mathrm{~mm}$. solution depth corresponds to $8.4 \pm .2 \mathrm{mg}$. per liter of hemin. This value was derived from experiments on the in vitro combination of hematin with normal serum, with purified serum albumin, and with crystalline, human serum albumin.4 Figure 4 illustrates such an experiment in which varying amounts of hemin have been added to a constant concentration of purified serum albumin. It is evident that Beer's law is

4 We are greatly indebted to Dr. Edwin J. Cohn and Dr. Laurence E. Strong for the supply of purified protein fractions of human plasma and for the sample of crystalline human serum albumin. The materials were prepared in the Department of Physical Chemistry, Harvard Medical School, under contracts recommended by the Committee on Medical Research, between the Office of Scientific Research and Development and Harvard University. The products were developed by the Department of Physical Chemistry from blood collected by the American Red Cross.

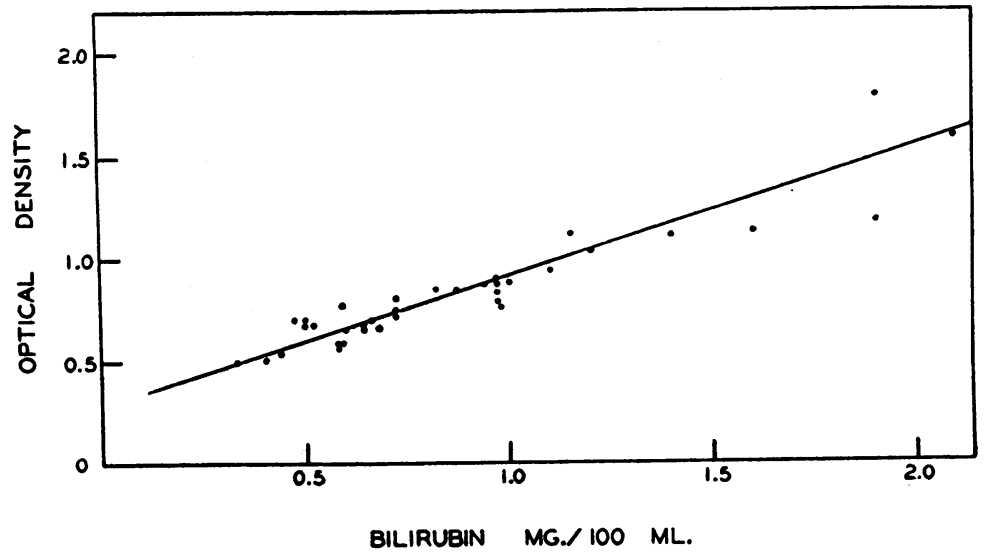

Fig. 3. Chart for Estmantion of Serum Blank

Optical density at $\mathbf{4 0 5} \mathrm{m \mu}$ of human sera containing different concentrations of bilirubin but no methemalbumin. 


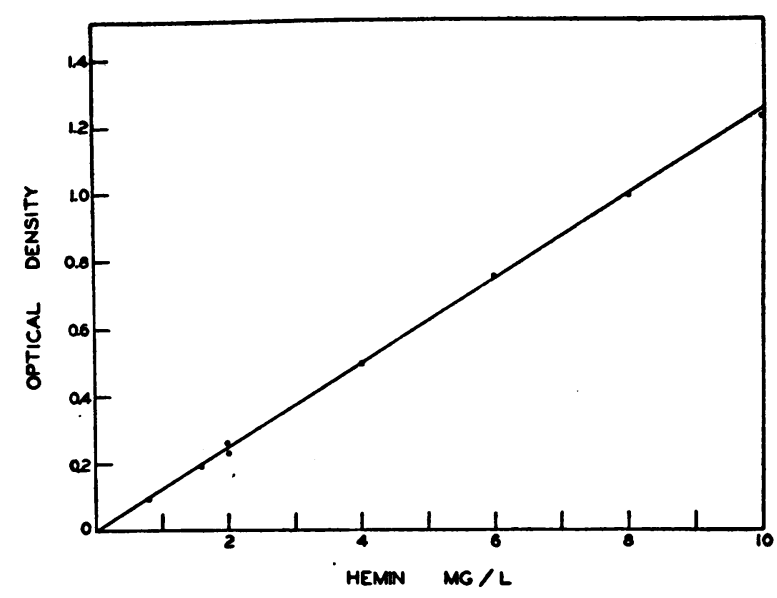

Fig. 4. Calibration Curve for Methemalbumin

Optical density at $405 \mathrm{~m} \mu$ of methemalbumin formed in vitro by the addition of hemin solutions to human serum albumin, fraction V, run 164 . The concentration of protein was $5 \mathrm{gm}$. per liter. Hemin concentrations were varied up to $10 \mathrm{mg}$. per liter.

followed closely within the range of measurement. The dissociation constant of methemalbumin is such that possible fluctuations in serum protein concentration do not affect the measurements. Similarly a five-fold dilution of serum for purposes of measurement does not introduce appreciable error. The absorption at $405 \mathrm{~m} \mu$ by methemalbumin is independent of $\mathrm{pH}$ within the range of $\mathrm{pH}$ 7.0 to 9.0 .

A typical experiment on the in vitro combination of hematin with serum albumin was conducted as follows. Hemin (Eastman Kodak Co.) was recrystallized in the laboratory from pyridine and chloroform according to the procedure of Hans Fischer (13). The human serum albumin was very kindly supplied by Dr. Edwin J. Cohn and Dr. Laurence E. Strong of the Physical Chemistry Department, Harvard University. The samples used in the present study were identified as human serum albumin, fraction V, run 164 and five-times recrystallized human serum albumin, run 179. Serum albumin, 125 mg., was dissolved in $10 \mathrm{ml}$. of $0.2 \mathrm{M}$ phosphate buffer, $\mathrm{pH}$ 7.5. Hemin, $50 \mathrm{mg}$., was dissolved in $10 \mathrm{ml}$. of $\mathrm{N} / 10$ sodium hydroxide and was made up to $100 \mathrm{ml}$. with distilled water. From this stock solution of hematin subdilutions were made in $\mathrm{N} / 100$ sodium hydroxide, usually starting with a five- or ten-fold dilution. The final test solution was made by adding $2 \mathrm{ml}$. of the protein solution and $1 \mathrm{ml}$. of the hematin solution to $2 \mathrm{ml}$. of $0.2 \mathrm{M}$ phosphate buffer, $\mathrm{pH}$ 7.5. The mixtures were held in a water bath for 15 minutes at $38^{\circ}$, then were cooled to room temperature and read in the Beckman spectrophotometer using cells of $10 \mathrm{~mm}$. light-path. 'The reference solution contained the protein, buffer, and $N / 100$ sodium hydroxide but no hematin. Figure 1 and Figure 4 are based upon data obtained by this procedure.
Although spectrophotometric identification of methemalbumin has been relied on chiefly, the chemical reactions recommended by Fairley (9) have also been applied to identify the pigment. The behavior of the pigment was tested with Stoke's reagent, dilute (10 per cent), and concentrated ammonium sulfide, sodium hydrosulfite, cyanide, and hydrogen peroxide. The differential reactions which identify the pigment were, in general, satisfied though they were not all applied in every case of methemalbuminemia.

No free hemoglobin was encountered in the sera of experimental subjects. If present, oxyhemoglobin could be readily detected spectrophotometrically by the aid of the band at $576 \mathrm{~m} \mu$. Oxyhemoglobin has a strong absorption band at $415 \mathrm{~m} \mu$ which would seriously complicate measurements on the $405 \mathrm{~m} \mu$ band of methemalbumin. Under such circumstances the less sensitive methemalbumin band at $623 \mathrm{~m} \mu$ could be used for the estimation.

Serum bilirubin was measured according to Malloy and Evelyn (14). Methemoglobin was estimated by the procedure of Horecker and Brackett (15), total hemoglobin by the method of Evelyn and Malloy (16).

\section{RESULTS}

Methemalbumin appeared in the serum of all individuals receiving the combined pamaquinequinine regimen, Group I. There was considerable variability in the levels attained at the end of the two-week period of therapy, the values ranging between 4 and $24 \mathrm{mg}$. per liter, Table I.

No methemalbumin appeared in the serum of any individual receiving either pamaquine alone, Group II, quinine alone, Group III, or pamaquine in combination with quinacrine, Group IV. It should be noted that pamaquine dosage was low, $30 \mathrm{mg}$. per day, in Group IV.

Methemoglobin developed in all patients receiving pamaquine either alone, Group II, in conjunction with quinine, Group I, or in conjunction with quinacrine, Group IV. The methemoglobin concentrations were somewhat higher under the combined therapy than under pamaquine alone. None of the methemoglobin appeared free in the serum; it was confined to red cells. The individuals receiving quinine alone, Group III, showed no significant increment in methemoglobin.

Bilirubin levels were slightly elevated in Group I on combined therapy but were normal in the other three groups when measured at the end of the two-week period of drug administration.

Hemoglobin concentrations dropped during malarial parasitemia but did not appear to be ap- 


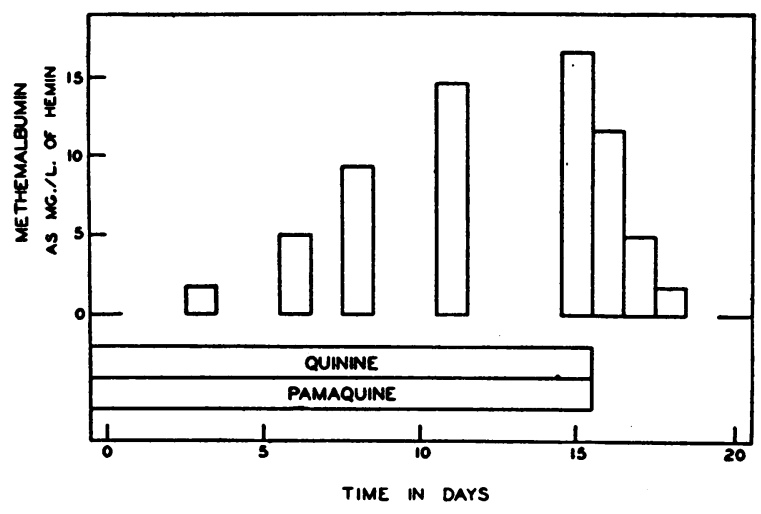

Fig. 5. Serum Methemalbumin Concentrations in Patient J. W. Showing Accumulation during Drug Administration and Disappearance Following CessaTION OF THERAPY

The drug dosage was pamaquine $90 \mathrm{mg}$. daily and quinine $1.8 \mathrm{gm}$. daily.

preciably affected by any of the drug regimens. None of the individuals of the four groups exhibited free hemoglobin either in serum or urine.

The accumulation and disappearance of methemalbumin were followed in one individual by frequent measurements, Figure 5. In this patient the concentration continued to rise throughout the course of drug administration, the rate of rise diminishing toward the end of therapy. The level dropped sharply when drug was discontinued and at 48 hours had fallen to one-third of the peak value. At five days no measurable methemalbumin remained.

The methemalbumin levels of patient J. K. are of particular interest in that she received two

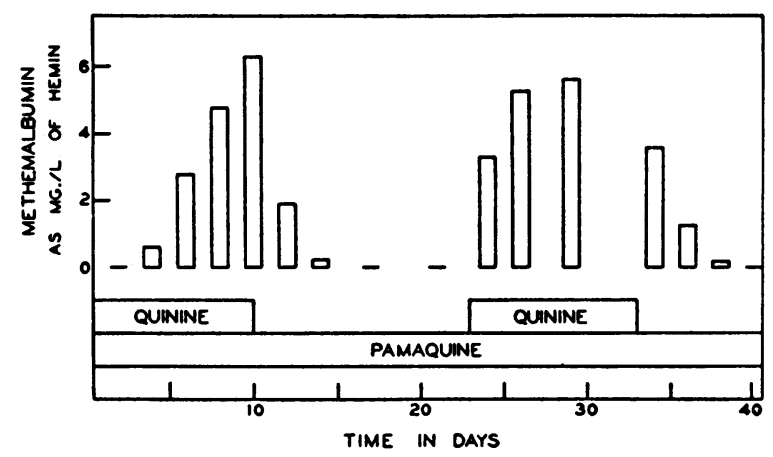

Fig. 6. Serum Methemalbumin Concentrations in Patient J. K. Receiving Two Cycles of Quinine AdMiNistration (1.8 GM. PER DAy) SUPERIMPosed UPON Continuous Dosage with Pamaquine (90 mg. Per DAY) cycles of quinine administration superimposed upon a continuous pamaquine regimen. As can be seen in Figure 6, methemalbumin appeared only during the periods of combined drug. This patient was a special case to whom the drugs were administered in the absence of malaria.

\section{DISCUSSION}

Methemalbumin exhibits characteristic spectrophotometric properties which distinguish it from other blood pigments such as hematin and methemoglobin. The absorption band at $623 \mathrm{~m} \mu$ has been utilized in previous work for the identification and estimation of the pigment. In the present study a band at $405 \mathrm{~m} \mu$ has been described which, because of its great intensity, permits more sensitive and more quantitative measurements.

In a series of individuals receiving pamaquine and quinine concurrently it has been possible to demonstrate a systematic production of methemalbumin. Such methemalbuminemia was not elicited by the administration of either drug alone or by pamaquine given in conjunction with quinacrine. Production of the pigment in these cases was related to a synergistic combination of the two drugs. It is important to note that the methemalbuminemia developed in the absence of frank hemolysis. The occurrence of the pigment has usually been associated with a massive hemolytic reaction though there have been instances reported, for example in pernicious anemia, where this has not been the case. The relationship of methemoglobin production to the generation of methemalbumin is not clear. Pamaquine alone gave rise to methemoglobin within the red blood cells but caused no methemalbumin to appear in the serum. The combination of pamaquine with quinine enhanced the methemoglobinemia to a moderate degree but this rise in itself certainly could not account for the generation of a totally new pigment, methemalbumin, in the serum.

The antimalarial drugs pamaquine and quinine have long been associated with disturbances in hemoglobin metabolism. Pamaquine therapy consistently gives rise to methemoglobinemia and more rarely in susceptible individuals to acute hemolytic reactions (12). There are a few cases in the literature in which hemoglobinuria has resulted from toxic doses of quinine (17). Quinine 
has been incriminated as one of the contributing factors in the pathogenesis of blackwater fever (18).

These reported instances of acute hemolysis are uncommon. They have been detected in the rare individual case by virtue of the spectacular appearance of free hemoglobin in the urine and serum. The regular appearance of methemalbumin in all the individuals receiving combined pamaquine-quinine therapy reveals a more subtle disturbance in pigment metabolism which is consistently evoked by the drug combination.

\section{SUMMARY AND CONCLUSIONS}

A procedure is described for the estimation of methemalbumin in serum. The method makes use of an absorption band at $405 \mathrm{~m} \mu$ and is applicable only in the absence of free hemoglobin.

Methemalbumin consistently appeared in the serum of individuals receiving quinine and pamaquine concurrently. Methemalbuminemia was not elicited by administration of either drug alone or of pamaquine in conjunction with quinacrine.

\section{BIBLIOGRAPHY}

1. Schumm, O., Hämatin als pathologischer Bestandteil des Blutes. Ztschr. f. Physiol. Chem., 1916, 97, 32.

2. Heilmeyer, L., Medizinische Spektrophotometrie. Gustav Fischer, Jena, 1933.

3. Fairley, N. Hamilton, and Bromfield, R. J., Laboratory studies in malaria and blackwater fever. Part III. A new blood pigment in blackwater fever and other biochemical observations. Tr. Roy. Soc. Trop. Med. \& Hyg., 1934, 28, 307.
4. Fairley, N. Hamilton, Methaemalbumin. Part II. Its synthesis, chemical behaviour, and experimental production in man and monkeys. The Quart. J. Med., 1941, 10, 115.

5. Foy, H., and Kondi, A., Spectrographic analysis of pigments in serum and urine of blackwater fever. Tr. Roy. Soc. Trop. Med. \& Hyg., 1938, 32, 49.

6. Fox, C. L., Jr., Spectrophotometry of Fairley's new blood pigment, methemalbumin. J. Clin. Invest., 1941, 20, 603.

7. Keilin, J., Reaction of human serum albumin with hematin and haem. Nature, 1944, 154, 120.

8. Pass, I. J., Schwartz, S., and Watson, C. J., The conversion of hematin to bilirubin following intravenous administration in human subjects. J. Clin. Invest., 1945, 24, 283.

9. Fairley, N. Hamilton, Methaemalbumin. Part I. Clinical Aspects. Quart. J. Med., 1941, 10, 95.

10. Fox, C. L., Jr., and Ottenberg, R., Acute hemolytic anemia from the sulfonamides. J. Clin. Invest., 1941, 20, 593.

11. Ross, J. F., and Paegel, B. L., Acute hemolytic anemia and hemoglobinuria following sulfadiazine medication. Blood, 1946, 1, 189.

12. Dimson, S. B., and McMartin, R. B., Pamaquin haemoglobinuria. Quart. J. Med., 1946, 15, 25.

13. Drake, N. L., Organic Syntheses, 1941, 21, 53.

14. Malloy, H. T., and Evelyn, K. A., The determination of bilirubin with the photoelectric colorimeter. J. Biol. Chem., 1937, 119, 481.

15. Horecker, B. L., and Brackett, F. S., A rapid spectrophotometric method for the determination of methemoglobin and carbonylhemoglobin in blood. J. Biol. Chem., 1944, 152, 669.

16. Evelyn, K. A., and Malloy, H. T., Microdetermination of oxyhemoglobin, methemoglobin, and sulfhemoglobin in a single sample of blood. J. Biol. Chem., 1938, 126, 655.

17. Vartan, C. K., and Discombe, G., Death from quinine poisoning. Brit. M. J., 1940, 1, 525.

18. Maegraith, B. G., Blackwater fever-modern theories. Trop. Dis. Bull., 1946, 43, 801. 